\title{
Hydrogen sulfide generation from L-cysteine in the human glioblastoma-astrocytoma U-87 MG and neuroblastoma SHSY5Y cell lines*
}

\author{
Patrycja Bronowicka-Adamska, Anna Bentke and Maria Wróbel ${ }^{\bowtie}$ \\ Chair of Medical Biochemistry, Jagiellonian University, Collegium Medicum, Kraków, Poland
}

Hydrogen sulfide $\left(\mathrm{H}_{2} \mathrm{~S}\right)$ is endogenously synthesized from L-cysteine in reactions catalyzed by cystathionine betasynthase (CBS, EC 4.2.1.22) and gamma-cystathionase (CSE, EC 4.4.1.1). The role of 3-mercaptopyruvate sulfurtransferase (MPST, EC 2.8.1.2) in $\mathrm{H}_{2} \mathrm{~S}$ generation is also considered; it could be important for tissues with low CTH activity, e.g. cells of the nervous system. The expression and activity of CBS, CTH, and MPST were detected in the human glioblastoma-astrocytoma (U-87 MG) and neuroblastoma (SHSY5Y) cell lines. In both cell lines, the expression and activity of MPST were the highest among the investigated enzymes, suggesting its possible role in the generation of $\mathrm{H}_{2} \mathrm{~S}$. The RP-HPLC method was used to determine the concentration of cystathionine and alphaketobutyrate, products of the CBS- and CTH-catalyzed reactions. The difference in cystathionine levels between cell homogenates treated with totally CTH-inhibiting concentrations of DL-propargylglycine and without the inhibitor was used to evaluate the activity of CBS. The higher expression and activity of CBS, CTH and MPST in the neuroblastoma cells were associated with more intensive generation of $\mathrm{H}_{2} \mathrm{~S}$ in the presence of $2 \mathrm{mM}$ cysteine. A threefold higher level of sulfane sulfur, a potential source of hydrogen sulfide, was detected in the astrocytoma cells in comparison to the neuroblastoma cells.

Key words: cystathionine, beta-synthase, gamma-cystathionase, glutathione, hydrogen sulfide, 3-mercaptopyruvate sulfurtransferase, sulfane sulfur

Received: 18 July, 2016; revised: 07 October, 2016; accepted: 05 November, 2016; available on-line: 14 March, 2017

*The results were presented at the 3rd International Conference on $\mathrm{H}_{2} \mathrm{~S}$ Biology and Medicine, Kyoto, Japan, 4-6 June, 2014, as a report (The activity of hydrogen sulfide generating enzymes in human cell lines. Nitric Oxide - Biology and Chemistry, Vol. 39, Suppl. 1 p. S33-S33).

e-mail: mbwrobel@cyf-kr.edu.pl

Abbreviations: CAT, cysteine aminotransferase; CBS, cystathionine $\beta$-lyase; CTH, $\gamma$-cystathionase; CTN, cystathionine; GSH, glutathione reduced form; MPST, 3-mercaptopyruvate sulfurtransferase; NBT/ $\mathrm{BCIP}$, nitroblue tetrazolium chloride/5-Bromo-4-chloro-3-indolyl phosphate, toluidine; PCA, perchloric acid

\section{INTRODUCTION}

In mammalian tissues, $\mathrm{H}_{2} \mathrm{~S}$ is synthesized endogenously from L-cysteine in regulated enzymatic pathways catalyzed by pyridoxal phosphate-dependent enzymes: cystathionine beta-synthase (CBS, EC 4.2.1.22), gamma-cystathionase (CTH, EC 4.4.1.1) and cysteine aminotransferase (CAT, EC 2.6.1.3) coupled with 3-mercaptopyruvate sulfurtransferase (MPST) (Wang, 2012) (Scheme 1A).

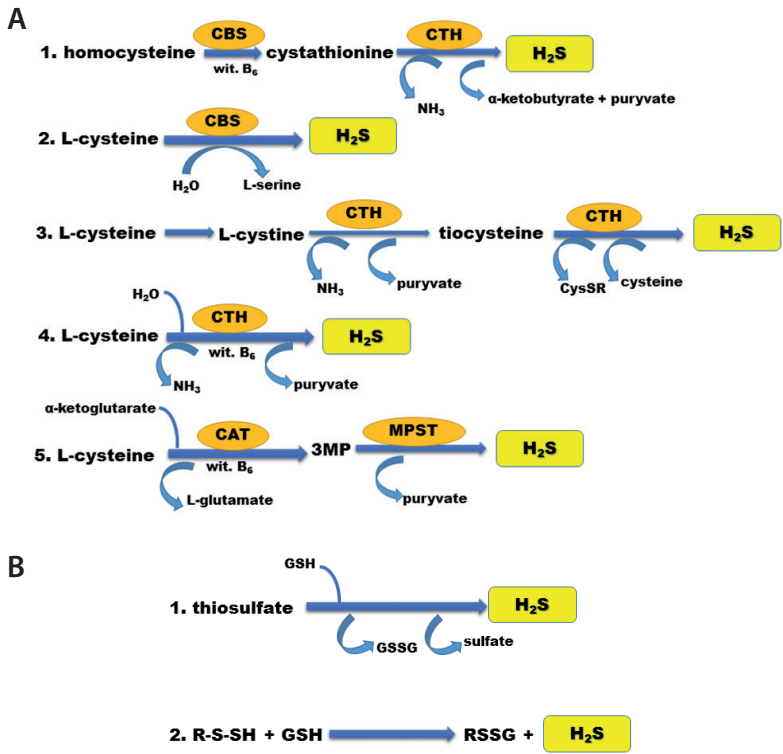

Scheme 1. The enzymatic (A) and non-enzymatic (B) reactions generating hydrogen sulfide.

Enzymatic reactions involve L-cysteine hydrolysis by CBS to L-serine and $\mathrm{H}_{2} \mathrm{~S}$, L-cystine transformation by CTH into thiocysteine, pyruvate (PA) and ammonia and subsequent thiocysteine transformation into $\mathrm{H}_{2} \mathrm{~S}$ and CysSR (S-thiolane). Another pathway includes the transformation of L-cysteine into 3-mercaptopyruvate (3MP) by cysteine aminotransferase (CAT) and, subsequently, $3 \mathrm{MP}$ desulfuration catalyzed by MPST resulting in $\mathrm{H}_{2} \mathrm{~S}$ and pyruvate formation (Scheme $1 \mathrm{~A}$ ). $\mathrm{H}_{2} \mathrm{~S}$ is formed in a redox reaction between thiosulfate or RSSH (persulfides) and biological thiols such as reduced glutathione (GSH) (Scheme 1B) (Libiad et al., 2014; Predmore et al., 2012). An additional pathway for the production of 3-MP and $\mathrm{H}_{2} \mathrm{~S}$ from D-cysteine by D-amino acid oxidase provides protection of cerebellar neurons from oxidative stress (Shibuya et al., 2013).

Astrocytes secrete and store antioxidative compounds, such as glutathione or ascorbate (Bartosz, 2006; Bèlanger \& Magistretti, 2009, Zabłocka \& Janusz, 2007). The cells play an important role in supplying precursors necessary for GSH synthesis in the neurons. GSH captured by astrocytes from the extracellular space is degraded in a reaction catalyzed by $\gamma$-glutamyl-transpeptidase $(\gamma-G T)$ to free cysteine (Zabłocka \& Janusz, 2007) (Scheme 2). The main transport system for cysteine in the astrocytes and neurons is mediated by the $\mathrm{Na}^{+}$dependent $\mathrm{X}_{\mathrm{AG}}$ and ASC (alanine-serine-cysteine) systems (Shanker et 


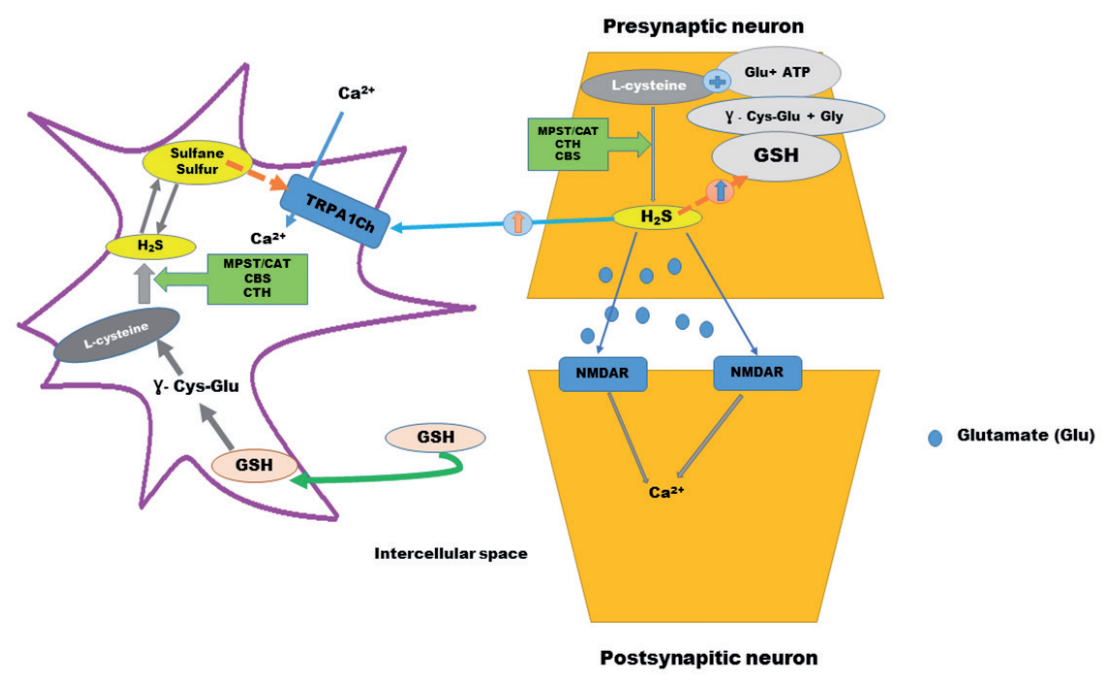

Scheme 2. The possible cooperation between the astrocytes and neural cells.

The Scheme is based on the scheme presented by Kimura (2013). $\mathrm{H}_{2} \mathrm{~S}$ activates TRPA 1 channels in the astrocytes in a similar way, but not as efficiently as polysulfides (Kimura, 2013, Moore \& Whiteman, 2005). $\mathrm{H}_{2} \mathrm{~S}$ has antioxidative properties and it increases the production of glutathione in neural cells (Kimura et al., 2010; Kimura \& Kimura, 2004). TRPA1Ch, transient receptor potential cation channel; subfamily A, member 1; NMDAR, N-methyl-D-aspartate receptor; Gly, Glycine; GSH, reduced glutathione

al., 2001a; Shanker et al., 2001b). The degradation product returns to neuron cells, where it is used as a substrate for glutathione synthesis. When compared to the neurons, astrocytes have the higher level of GSH, both in vivo and in cell cultures (Dringen et al., 2000). Functional neuron-glial cell interrelations provide an important mechanism participating in brain functions control (Scheme 2).

The anaerobic conversion of cysteine can lead to the formation of hydrogen sulfide $\left(\mathrm{H}_{2} \mathrm{~S}\right)$. It is known that endogenously formed $\mathrm{H}_{2} \mathrm{~S}$ acts as a neuromodulator and neuroprotector in the brain (Panthi et al., 2016; Paul \& Snyder, 2015). By means of activating NMDA receptors and increasing the response of peripheral neurons, $\mathrm{H}_{2} \mathrm{~S}$ may play a significant role in processes associated with memorization and learning (Ishigami et al., 2009; Shibuya et al., 2009). An increased synthesis of $\mathrm{H}_{2} \mathrm{~S}$ has been observed in patients with Down's syndrome and septic shock, while its decreased generation has been noted in Alzheimer's disease. $\mathrm{H}_{2} \mathrm{~S}$ activates TRPA1 channels in the astrocytes in a similar way, but not as efficiently as polysulfides (Kimura, 2013; Moore \& Whiteman, 2005). $\mathrm{H}_{2} \mathrm{~S}$ has antioxidative properties and it increases the production of glutathione in neural cells (Kimura et al., 2010; Kimura \& Kimura, 2004).

The study was conducted to determine the activity and expression of the enzymes: CBS, CTH and MPST involved in the production of $\mathrm{H}_{2} \mathrm{~S}$ in the human glioblastoma-astrocytoma (U-87 MG) and neuroblastoma (SHSY5Y) cell lines. The results of our previous studies (Jurkowska et al. 2011) showed the expression of CTH and MPST genes in the human neoplastic cell lines: astrocytoma U373 and neuroblastoma SH-SY5Y. The CTH and MPST enzymes, through an increase in sulfane sulfur levels, might increase $\mathrm{H}_{2} \mathrm{~S}$ levels. The RPHPLC method was used to detect and determine the amount of direct and indirect products of the CBS- and CTH-catalyzed reactions, such as cystathionine, cysteine, and glutathione. The difference in the cystathionine level between the cells incubated with totally CTH-inhibiting concentrations of DL-propargylglycine (PPG) and without the inhibitor was used to evaluate the activity of CBS. Differences in the expression and activity of CBS, CTH, and MPST point to a higher intensity of $\mathrm{H}_{2} \mathrm{~S}$ generation in the neuroblastoma cells, which was confirmed by the higher level of $\mathrm{H}_{2} \mathrm{~S}$ in SHSY5Y cells determined using the $\mathrm{H}_{2} \mathrm{~S}$ trapping method of Kartha et al. (2012).

\section{MATERIAL AND METHODS}

Chemicals. L-Glutathione reduced (GSH), L-cysteine, cystathionine (CTN), DL-homoserine (HSer), 1-fluoro-2,4-dinitrobenzene (DNFB), bathophenanthroline-disulfonic acid disodium salt (BPDS), acetonitrile, pyridoxal phosphate (PLP), $\beta$-nicotinamide adenine dinucleotide reduced disodium salt hydrate (NADH), L-lactic dehydrogenase (LDH), 3-mercaptopyruvate acid sodium salt, D,L-dithiothreitol, (DTT), N-ethylmaleimide (NEM), DL-propargylglycine (PPG), sodium dihydrogen phosphate dihydrate pure, sodium sulfite, chloroform, isopropanol, agarose, sodium hydrosulfide hydrate, sodium chloride, Folin-Ciocalteu's phenol reagent, iron (III) nitrate nonahydrate, sodium thiosulfate pentahydrate, sodium carbonate and N,N-dimethyl-p-phenylenediamine sulfate salt, Coomassie Blue G250 were obtained from Sigma-Aldrich (Poznan, Poland). Trifluoroacetic acid (TFA), 2-mercaptoethanol were purchased from FlukaChemie GmbH (Buchs, Switzerland). Ethanol and 70\% perchloric acid (PCA), $38 \%$ formaldehyde, 65\% nitric acid, 38\% hydrochloric acid, ammonia solution $25 \%$ pure, sodium potassium tarate, copper sulphate pentahydrate, potassium dihydrogen phosphate, ferric chloride, zinc acetate dehydrate pure, sodium hydroxide were from Polskie Odczynniki Chemiczne S.A. (Gliwice, Poland). $N^{\varepsilon}$-methyllysine was obtained from Bachem (Bubendorf, Switzerland). DMEM/High glucose, trypsin $0.25 \%$, fetal bovine serum and penicillin-streptomycin solution were purchased from Thermo Scientific (Waltham, MA, USA). Trizol, ethidium bromide and EDTA-disodium salt dihydrate were obtained from Lab-Empire S.A. (Rzeszow, Poland). Potassium cyanide was from Merck Sp. z o.o. (Warszawa, Poland). Reverse Transcriptase M-MuLV was obtained from Roche Diagnostics Polska Sp. z o.o. and Promega Poland (Warszawa, Poland). Polymerase DNA Dream Taq ${ }^{\mathrm{TM}}$, Gene Ruler $100 \mathrm{bp}$ DNA Ladder, Oligo(dT)18 primer and dNTP Mix were obtained from Abo Sp. z o.o. (Gdańsk, Poland). RIPA buffer was from TermoScientific (Rockford, USA). Antibodies: anti-CBS and -CTH were from Abnova (Taiwan), anti-MPST was from Gene'Tex (Taiwan), anti- $\beta$-actin from Sigma-Aldrich (Poznan, Poland), anti-alpha-tubuline, alkaline phosphatase-conjugated goat anti-rabbit IgG antibody and anti-mouse $\operatorname{IgG}$ antibody were from Proteintech (Chicago, IL, USA). NBT/BCIP (nitroblue tetrazolium chloride/5-bromo-4-chloro-3-indolyl phosphate), toluidine was from Roche (Warszawa, Poland). All the chemicals and HPLC solvents were 
gradient grade. Water was deionized by passing through an EASY pure RFcompact ultrapure water system.

Cell lines. Cell culture. Human glioblastoma-astrocytoma (U-87 MG) and neuroblastoma (SHSY5Y) cell lines were grown in a monolayer in Dulbecco's Modified Eagle Medium (DMEM) supplemented with 10\% fetal bovine serum and antibiotics $(100 \mathrm{U} / \mathrm{ml}$ penicillin and $100 \mu \mathrm{g} / \mathrm{ml}$ streptomycin), in plastic culture dishes (100 $\mathrm{mm}$ in diameter), at $37^{\circ} \mathrm{C}$ in a humidified atmosphere containing $5 \% \mathrm{CO}_{2}$. Cell lines were purchased from the European Collection of Cell Cultures (ECACC-SIGMA Aldrich, Poznań, Poland).

Cytotoxicity of L-cysteine. The cells were seeded in triplicates into 96-microwell plates at density of $20 \times 10^{3}$ cells/well and incubated for $24 \mathrm{~h}$ with or without $2 \mathrm{mM}$ L-cysteine in DMEM medium supplemented with 10\% FBS. Colorimetric assay was performed according to the manufacturer instructions (Cytotoxicity Detection Kit, Roche, Thermo Fisher Scientific). Absorbance of the colored product - formazane - was measured at $490 \mathrm{~nm}$ by microreader (EPOCH, BioTEK).

Expression of MPST, CTH, CBS in cell lines. RNA extraction. The total RNA was extracted using TRIZOL, according to the protocol provided by the manufacturer. The quality of RNA samples was determined by spectrophotometric analysis $\left(\mathrm{A}_{260} / \mathrm{A}_{280}\right)$ and electrophoresis in $2.5 \%$ agarose gel followed by staining with ethidium bromide.

Reverse Transcription of RNA. Total RNA from the cell samples was reverse-transcribed using First-Stand cDNA synthesis kit according to the manufacturer instructions (Promega, Company, Warszawa, Poland). For reverse transcription (RT) $3 \mu \mathrm{g}$ of total RNA was mixed with $1 \mu$ l Oligo $(\mathrm{dT})_{15}(0.5 \mu \mathrm{g} /$ reaction $)$ and nuclease-free water and heated in a $70^{\circ} \mathrm{C}$ heat block for 5 minutes. After preincubation the reverse transcription reaction mix containing: $4 \mu \mathrm{l}$ of GoScript ${ }^{\mathrm{TM}} 5 \mathrm{X}$ reaction buffer, $3 \mu \mathrm{l}$ of $\mathrm{MgCl}_{2}$ (final concentration $1.5-5.0 \mathrm{mM}$ ), $1 \mu \mathrm{l}$ of deoxyribonucleotide triphosphates (dNTPs, $10 \mathrm{mM}$ ), $1 \mu \mathrm{l}$ of Recombinant RNases Ribonuclease Inhibitor (20 U/ $\mu \mathrm{l})$ and $1 \mu \mathrm{l}$ of GoScript ${ }^{\mathrm{TM}}$ Reverse Transcriptase were prepared.

cDNA Synthesis and RT-PCR analysis. Expression of MPST, CTH, CBS and $\beta$-actin was analyzed with RT-PCR as previously described by Jurkowska et al. (2011) with modifications. Amplification of cDNA samples was performed in a $12.5 \mu \mathrm{l}$ reaction volume containing: $1 \mu \mathrm{l}$ of synthesized cDNA, $0.2 \mu \mathrm{M}$ of each of gene-specific primer pair, $0.04 \mathrm{U} / \mu \mathrm{l}$ of DNA polymerase in $10 \mathrm{mM}$ Tris-HCl buffer $\mathrm{pH} 8.8,0.2 \mathrm{mM}$ of each dNTPs and nuclease-free water. The temperature profile of RT-PCR amplification for the MPST consisted of activation of Taq polymerase at $94^{\circ} \mathrm{C}$ for $5 \mathrm{~min}$, denaturation of cDNA at $94^{\circ} \mathrm{C}$ for $30 \mathrm{~s}$, primer annealing at $56^{\circ} \mathrm{C}$ for $30 \mathrm{~s}$, elongation at $72^{\circ} \mathrm{C}$ for $2 \mathrm{~min}$ for the following 28 cycles and was finished by the extension step for $8 \mathrm{~min}$. For the CTH gene, after the initial denaturation for $5 \mathrm{~min}$ at $94^{\circ} \mathrm{C}$, amplification was performed under the following conditions: $94^{\circ} \mathrm{C}$ for $30 \mathrm{~s}, 51^{\circ} \mathrm{C}$ for $1 \mathrm{~min}$ and $72^{\circ} \mathrm{C}$ for $8 \mathrm{~min}$ for 28 cycles, with the final incubation at $72^{\circ} \mathrm{C}$ for $10 \mathrm{~min}$. For the $\mathrm{CBS}$ gene, after the initial denaturation for $5 \mathrm{~min}$ at $94^{\circ} \mathrm{C}$, amplification was performed under the following conditions: $94^{\circ} \mathrm{C}$ for $30 \mathrm{~s}, 60^{\circ} \mathrm{C}$ for $30 \mathrm{~s}$ and $72^{\circ} \mathrm{C}$ for $2 \mathrm{~min}$ for 38 cycles, with the final incubation at $72^{\circ} \mathrm{C}$ for $8 \mathrm{~min}$. For $\beta$-actin gene, after the initial denaturation for $5 \mathrm{~min}$ at $94^{\circ} \mathrm{C}$, amplification was performed under the following conditions: $94^{\circ} \mathrm{C}$ for $30 \mathrm{~s}, 54^{\circ} \mathrm{C}$ for $30 \mathrm{~s}$ and $72^{\circ} \mathrm{C}$ for $2 \mathrm{~min}$ for 28 cycles, with the final incubation at $72^{\circ} \mathrm{C}$ for $8 \mathrm{~min}$. The following specific primers (Oligo Company) were used:

MPST - F: 5'TCT'TCGACATCGACCAGTGC' and R: 5'TGTGAAGGGGATGTTCACGG3'

CTH - F: 5'GCAAGTGGCATCTGAAT'T'TG3' and R: 5'CCCAT'TACAACATCACTGTGG3'

CBS - F: 5'CGCTGCGTGGTCATTCTGCC3' and R: 5'TCCCAGGATTACCCCCGCCT3'

$\beta$-actin - F: 5'CTGTCTGTCACCACCAT3' and R: 5'GCAACTAAGTCATAGTCCGC3'

$\beta$-actin was used as the internal standard to normalize all samples for potential variations in mRNA content. PCR reaction products were separated electrophoretically in a $2.5 \%$ agarose gel, stained with ethidium bromide and directly visualized under UV light and photographed.

Western blotting analysis. The cells were suspended in RIPA buffer, containing proteinase inhibitors cocktail, sonicated $3 \times 5$ s at $4^{\circ} \mathrm{C}$ (BandelinSonoplus GM 70) and centrifuged at $14000 \times g$ for $15 \mathrm{~min}$ - supernatants were used for further analysis. The relative amount of CBS, CTH, MPST was determined by Western blotting using the appropriate antibody: anti-CBS (1:1000), anti-CTH $(1: 1000)$, anti-MPST (1:1000). Anti- $\beta$-actin (1:5000) and anti-alpha-tubuline $(1: 5000)$ antibodies were used to check for equal loading. Proteins of interest were detected with alkaline phosphatase-conjugated goat anti-rabbit IgG antibody (1:2000) or with alkaline phosphatase-conjugated goat anti-mouse IgG antibody (1:2000). Proteins were visualized with NBT/BCIP staining solution.

Detection of $\mathbf{H}_{2} \mathrm{~S}$. The $\mathrm{H}_{2} \mathrm{~S}$ produced during the incubation of the cell culture with $\mathrm{H}_{2} \mathrm{~S}$-releasing compounds was trapped as zinc sulfide in the zinc agarose layer according to Kartha et al. (2012). The standard curve was linear at the concentration range of $0-250 \mu \mathrm{M}$ with correlation coefficient of 0.994 .

Enzymes assay. Cell homogenization. U-87 MG and SHSY5Y cells $\left(3.5-5 \times 10^{6}\right.$ cells $)$ were suspended in $0.1 \mathrm{M}$ phosphate buffer $\mathrm{pH} 7.5$, in the proportion of $1 \mathrm{mln}$ cells $/ 0.07 \mathrm{ml}$ of the buffer, sonicated $3 \times 5 \mathrm{~s}$ at $4^{\circ} \mathrm{C}$ (BandelinSonoplus GM 70). After centrifugation at $1600 \times g$ for $10 \mathrm{~min}$, the supernatant was used for the determination of protein concentration, sulfane sulfur levels and the activity of MPST and CTH. For RPHPLC analyses cells were suspended in $0.1 \mathrm{ml} 0.9 \%$ $\mathrm{NaC} / 170 \%$ PCA/1 mM BPDS. The sediment was separated by centrifugation at $1400 \times g$ for $10 \mathrm{~min}$, and supernatant was stored at $-80^{\circ} \mathrm{C}$ until analysis.

MPST activity. MPST activity was assayed according to the method of Valentine and Frankelfeld, (1974) following a procedure described in our earlier paper (Wróbel et al. 2004). The incubation mixture contained: 250 $\mu \mathrm{l}$ of $0.12 \mathrm{M}$ sodium phosphate buffer, $\mathrm{pH} 8.0,50 \mu \mathrm{l}$ of $0.5 \mathrm{M}$ sodium sulfite, $50 \mu$ l of $0.15 \mathrm{M}$ dithiothreitol, $50 \mu \mathrm{l}$ of homogenates, $50 \mu \mathrm{l}$ of $\mathrm{H}_{2} \mathrm{O}$ and $50 \mu \mathrm{l}$ of $0.1 \mathrm{M}$ 3 -mercaptopyruvate acid sodium salt in a final volume of $500 \mu \mathrm{l}$. Mixture was incubated for $15 \mathrm{~min}$. To stop the reaction $250 \mu \mathrm{l}$ of $1.2 \mathrm{M}$ PCA was added. Samples were centrifuged at $1600 \times g$ for $5 \mathrm{~min}$, and $100 \mu \mathrm{l}$ of supernatant was transferred to $1350 \mu \mathrm{l}$ of mixture that contained: $1200 \mu \mathrm{l}$ of $0.12 \mathrm{M}$ sodium phosphate buffer, $\mathrm{pH}$ 8.0, $100 \mu \mathrm{l}$ of $0.1 \mathrm{M} \mathrm{N}$-ethylmaleimide, $50 \mu \mathrm{l}$ of $\mathrm{NADH}$ $5 \mathrm{mg} / \mathrm{ml}$. After equilibration at $37^{\circ} \mathrm{C}, 2.5 \mu \mathrm{l}$ of lactate dehydrogenase (7 IU) was added, and the decrease in absorbance was measured at $340 \mathrm{~nm}$. The enzyme activity was expressed as nmoles of pyruvate produced during 1 min incubation at $37^{\circ} \mathrm{C}$ per $1 \mathrm{mg}$ of protein.

CTH activity. Cystathionase activity was determined using Matsuo and Greenberg's method (1958) with modifications described by Czubak et al. (2002). The 
incubation mixture contained: $25 \mu \mathrm{l}$ of $1.3 \mathrm{mM}$ PLP, $25 \mu \mathrm{l}$ of $0.02 \mathrm{mM}$ EDTA, $250 \mu \mathrm{l}$ of $45 \mathrm{mM}$ cystathionine solution in $0.1 \mathrm{M}$ phosphate buffer, $\mathrm{pH} 7.5$ (2.5 $\mathrm{mg}$ of cystathionine per sample) and $75 \mu \mathrm{l}$ of homogenate and $0.1 \mathrm{M}$ phosphate buffer, $\mathrm{pH} 7.5$ containing $0.05 \mathrm{mM} 2$-mercaptoethanolin in the final volume of $650 \mu \mathrm{l}$. The reaction was stopped after $15 \mathrm{~min}$ of incubation at $37^{\circ} \mathrm{C}$ by placing $125 \mu \mathrm{l}$ of the incubation mixture in $25 \mu \mathrm{l}$ of $10 \%$ PCA. Samples were centrifuged at $1600 \times \mathrm{g}$ for $10 \mathrm{~min}$, and $25 \mu \mathrm{l}$ of supernatant was transferred to $625 \mu \mathrm{l}$ of $0.194 \mathrm{mM} \mathrm{NADH}$ solution and kept at $37^{\circ} \mathrm{C}$. Control samples, without 45 $\mathrm{mM}$ cystathionine, were prepared in the same way as the examined samples. After $10 \mathrm{~s}$ of the measurement (absorbance at $340 \mathrm{~nm}$ ), $25 \mu \mathrm{l}$ (9.06 IU) of lactate dehydrogenase $(\mathrm{LDH})$ was added and measurement was continued up to $180 \mathrm{~s}$. The difference between the initial value of absorbance (before adding LDH) and the lowest value (after adding LDH) corresponded to the amount of alpha-ketobutyrate formed in the course of the cystathionase reaction. Cystathionase activity was expressed as nmoles of $\alpha$-ketobutyrate formed during $1 \mathrm{~min}$ incubation at $37^{\circ} \mathrm{C}$ per $1 \mathrm{mg}$ of protein.

CBS activity. The activity of CBS was examined in cells homogenates in the presence of DL-homoserine as substrate after 15 minutes incubation at $37^{\circ} \mathrm{C}$ according to the description in Bronowicka-Adamska et al. (2011). PPG, in the concentration of $0.7 \mathrm{mM}$, was used to completely inhibit the activity of CTH in both cell lines. The level of cystathionine was determined using the HPLC method described by Bronowicka-Adamska et al. (2015). The CBS activity was expressed as pmoles of cystathionine formed during $1 \mathrm{~min}$ incubation at $37^{\circ} \mathrm{C}$ per $1 \mathrm{mg}$ of protein.

Sulfane sulfur. Sulfane sulfur was determined by the method of Wood, (1987), based on cold cyanolysis and colorimetric detection of ferric thiocyanate complex ion. Incubation mixtures in a final volume $880 \mu$ l contained: $20 \mu \mathrm{l}$ of $1 \mathrm{M}$ ammonia solution, $20 \mu \mathrm{l}$ of homogenate, $740 \mu \mathrm{l}$ of $\mathrm{H}_{2} \mathrm{O}$ and $100 \mu \mathrm{l}$ of $0.5 \mathrm{M}$ sodium cyanide. Incubation was performed for $45 \mathrm{~min}$ at room temperature. After incubation, thiocyanate was estimated calorimetrically at $460 \mathrm{~nm}$ after the addition of $20 \mu \mathrm{l}$ of $38 \%$ formaldehyde and $40 \mu \mathrm{l}$ of ferric nitrate reagent. Sulfane sulfur level was expressed as nmoles of SCNproduced per $1 \mathrm{mg}$ of protein.

Proteins. Protein concentration was determined with the method of Lowry et al. (1951) using crystalline bovine serum albumin as a standard. Protein concentration measurement with Bradford assay was used for the determination of protein in Western blotting analysis (Bradford, 1976).

RP-HPLC (Reverse Phase High Performance Liquid Chromatography). The level of cystathionine, alpha-ketobutyrate and the reduced glutathione (GSH) in the incubation mixtures were determined using the RP-HPLC method of Dominick et al. (2001) with modifications (Bronowicka-Adamska et al., 2015; BronowickaAdamska et al., 2011; Wróbel et al., 2009).

Table 1. The mean value of MPST, CTH, CBS activity, and sulfane sulfur level in U-87 MG and SHSY5Y cell.

\begin{tabular}{lllll}
\hline \multirow{2}{*}{ Cell line } & MPST & CTH & CBS & Sulfane Sulfur \\
\cline { 2 - 5 } & $\mathrm{nmol} \cdot \mathrm{mg}^{-1} \mathrm{~min}^{-1}$ & & $\mathrm{pmol} \cdot \mathrm{mg}^{-1} \cdot \mathrm{min}^{-1}$ & $\mathrm{nmol} \cdot \mathrm{mg}$ protein \\
\hline SHSY5Y & $674 \pm 93$ & $5.15 \pm 1.46$ & $17.3 \pm 2.7$ & $41 \pm 15$ \\
\hline U87MG & $196 \pm 23$ & $3.29 \pm 0.83$ & $1.34 \pm 0.2$ & $139 \pm 47$ \\
\hline
\end{tabular}

Values are the mean of four to five measurements from three independent experiments.

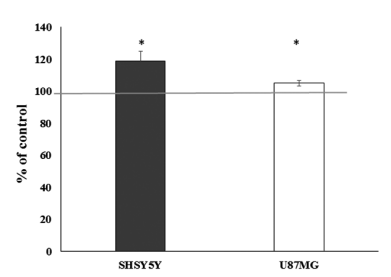

Figure 1. The level of hydrogen sulfide in homogenates of U-87 MG and SHSY5Y cells after $24 \mathrm{~h}$ incubation with $2 \mathrm{mM}$ L-cysteine.

The experiments were carried out for control homogenates of U-87 MG, SHSY5Y cells with $2 \mathrm{mM}$ L-cysteine as the main endogenous substrate for the hydrogen sulfide producing enzymes. The data represent the mean value from three independent experiments. Statistical analysis was performed using the Student's $t$-test $\left({ }^{*} P<0.05\right)$.

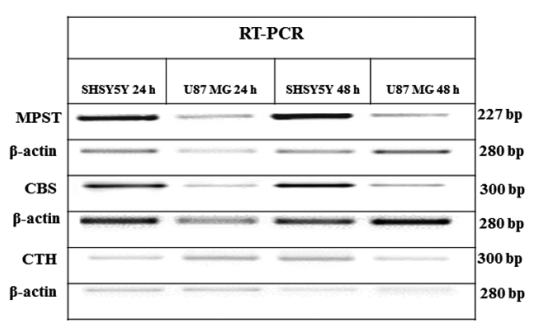

Figure 2. RT-PCR analysis of MPST, CBS and CTH expression in SHSY5Y and U-87 MG cell lines.

One set of representative results is shown. $\beta$-actin was used as the internal control. The length of the products: MPST, $227 \mathrm{bp}$; CBS, 300 bp; CTH, 300 bp; $\beta$-actin, 280 bp. Specific primers and temperature profiles for particular proteins are given in Material and Methods.

Statistical analysis. All results were expressed as means \pm S.D. The significance of the differences between controls and investigated samples were calculated using Student's Test $(P<0.05)$. Each experiment was repeated minimum three times.

\section{RESULTS AND DISCUSSION}

The studies showed U-87 MG and SHSY5Y cells capacity of hydrogen sulfide formation from L-cysteine and an increased level of hydrogen sulfide in the neuroblastoma - SHSY5Y cells (Fig. 1) by about 20\%, as compared to the control cells without L-cysteine, and only by about $5 \%$ in the glioblastoma-astrocytoma (U-87 MG cells) after $24 \mathrm{~h}$ of incubation with $2 \mathrm{mM} \mathrm{L-cysteine}$ (Fig. 1). The cytotoxic effect on the SHSY5Y and U-87 MG cell lines after 24 hours of incubation with $2 \mathrm{mM} \mathrm{L-}$ cysteine was lower than $10 \%$ for both cell lines.

Table 1 shows the activity of CTH, MPST, CBS and the level of sulfane sulfur in the SHSY5Y and U-87 MG cells. One can summarize that all the enzymatic pathways (Scheme 1) generating $\mathrm{H}_{2} \mathrm{~S}$ can occur in the investigated cell lines. CBS is regarded as the principal enzyme responsible for $\mathrm{H}_{2} \mathrm{~S}$ synthesis in the brain, while CTH plays a similar role in the circulatory system (Abe \& Kimura, 1996). More than tenfold higher CBS activity and three fold higher MPST activity were estimated in the neuroblastoma cells, as compared to the astrocytoma cells. Therefore, the neuroblastoma cells have potentially higher capacity of $\mathrm{H}_{2} \mathrm{~S}$ generation from cysteine than astrocytoma. In the neuroblastoma cells, specific activity of MPST being the highest among the investigated enzymes and the highest expression of MPST (Fig. 2 and 


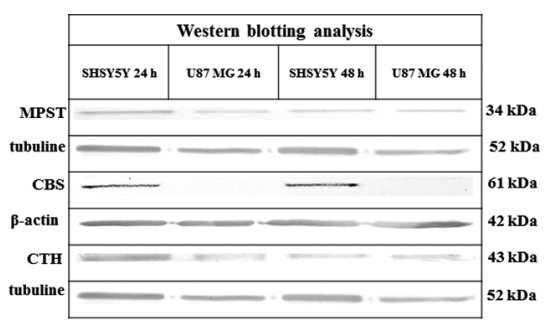

B

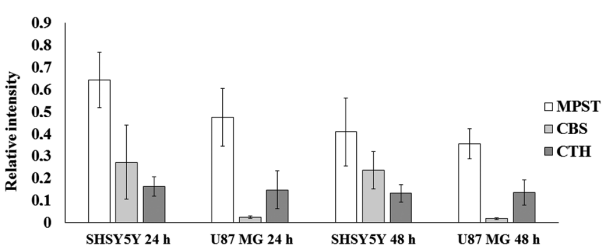

Figure 3. Western blotting analysis of MPST, CBS, CTH proteins in SHSY5Y and U-87 MG cell lines.

(A) Western blotting analysis. Western blot analysis of MPST, CBS and $\mathrm{CTH}$ was performed for the cell lines using a mixture of rabbit- (MPST) and mouse-derived (CBS, CTH, $\beta$-actin and alpha-tubuline) primary antibodies with the appropriate mixture of alkaline phosphatase-conjugated secondary antibodies. One set of representative results is shown. $\beta$-Actin and alpha-tubuline were used as the internal control of protein loading; $20 \mu \mathrm{g}$ of protein was added to each lane. For details see Material and Methods. (B) The relative intensity normalized to $\beta$-actin and alpha-tubulin. Analysis of protein bands imaged with the ChemiDoc ${ }^{\mathrm{TM}}$ MP. The relative intensity value is the average from three independent experiments. The relative intensity was normalized using $\beta$-actin and alphatubulin signals, the average of which was taken as one.

3) can both suggest that this enzyme plays a role in the generation of $\mathrm{H}_{2} \mathrm{~S}$.

On the other hand, the sulfane sulfur level was more than threefold higher in the astrocytoma cells, which can suggest that a nonenzymatic release of $\mathrm{H}_{2} \mathrm{~S}$ from sulfane sulfur-containing compounds (Scheme 2) is possible. It seems probable that in the neuroblastoma cells, $\mathrm{H}_{2} \mathrm{~S}$, functioning as a neurotransmitter, is synthesized in response to the signal-to-date. The astrocytoma cells, in turn, can release $\mathrm{H}_{2} \mathrm{~S}$ from sulfane sulfur reserves to transmit a signal within the astrocyte network (Perea \& Araque, 2003; Zabłocka \& Janusz, 2007). The conditions under which physiological signals mobilize $\mathrm{H}_{2} \mathrm{~S}$ from sulfane sulfur stores have not been elucidated so far (Paul \& Snyder, 2015).

The U-87 MG astrocytoma cells had the higher level of GSH in comparison to the neuroblastoma cells, which confirms the differences in glutathione content between the astrocytes and neurons (Dringen et al. 2000) (Fig. 4).The high levels of glutathione in the astrocytes seem to be essential for neurons protection e.g.: against the toxicity of reactive oxygen species. In the control cultures and cultures with PPG (inhibitor of CTH) added in the concentration of $0.7 \mathrm{mM}$, both the level of $\alpha$-ketobutyrate and the level of cysteine were undetectable. The inhibition of CTH with PPG in the astrocytoma cells resulted in a diminished level of GSH after 15 min of incubation, but no such effect was seen in the neuroblastoma cells (Fig. 4). This may suggest that the pathway of cysteine generation through CTH-catalyzed reaction is important in the U-87 MG cells, while the SHSY5Y cells depend to a great extent on an exogenous source of cysteine. The importance of the transsulfuration pathway in astrocytes and glioblastoma/astrocytoma cells as a reserve pathway when the demand for glutathione is high was recently discussed by McBean (2012). Changes in cystathionine levels were not

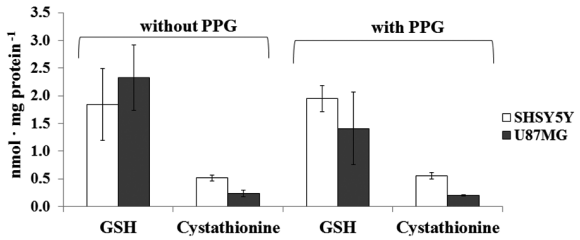

Figure 4. The level of GSH and cystathionine in U-87 MG and SHSY5Y cells.

The experiments were carried out for control homogenates of U-87 MG, SHSY5Y cells with or without PPG as the inhibitor of CTH in concentration of $0.7 \mathrm{mM}$ for both cells lines. The homogenates were incubated with PPG for 15 minutes. The data represent the mean value from three independent experiments.

observed in either of the cell lines in response to PPG after 15 min of incubation (Fig. 4).

\section{CONCLUSIONS}

In the glioblastoma-astrocytoma (U-87 MG) and neuroblastoma (SHSY5Y) cells, the pathway catalyzed by enzymatic tandem CAT/MPST can play a role in the generation of hydrogen sulfide from cysteine. In the neuroblastoma cells, the pathway from methionine to cysteine through the CBS and CTH reactions seems to play a more significant role as compared to the astrocytoma cells. The higher activity and expression of enzymes involved in $\mathrm{H}_{2} \mathrm{~S}$ generation from cysteine, in the neuroblastoma cells, provide an opportunity for more rapid response in $\mathrm{H}_{2} \mathrm{~S}$ production than in the astrocytoma cells. However, in the astrocytoma cells, the elevation of $\mathrm{H}_{2} \mathrm{~S}$ seems to be possible by releasing it from the pool of sulfane sulfur. Panthi et al. (2016) reviewed possible physiological roles of $\mathrm{H}_{2} \mathrm{~S}$ in neurons protection from oxidative stress or in the upregulation of the GABA $\beta$-receptors at pre- and postsynaptic sites along with astrocytes roles in the regulation of neurotransmitter levels or neuronal excitability.

\section{Acknowledgements}

This work was supported by a grant from the National Committee for Scientific Research No. K/DSC/001372.

\section{Conflicts of Interest}

The authors declare no conflict of interest.

\section{Contributions}

P.B-A provided the experimental data. A.B performed and developed the Western blotting analysis. M.W. provided suggestions for the experiments. P.B-A and M.W. planned the experiments and wrote the paper.

\section{REFERENCES}

Abe K, Kimura H (1996) The possible role of hydrogen sulfide as an endogenous neuromodulator. I Neurosci 16: 1066-1071. doi: $10.1017 /$ S1740925X09000064

Araque A (2008) Astrocytes process synaptic information. Neuron Glia Biol 4: 3-10.

Bartosz G (2006) Druga twarz tlenu. Wyd. PWN (in Polish).

Bélanger M, Magistretti PJ (2009) The role of astroglia in neuroprotection. Dialogues Clin Neurosc 11: 281-295.

Bonansco Ch, Couve A, Perea G, Ferradas CA, Roncagliolo M, Fuenzalida M (2011) Glutamate released spontaneously from astrocytes sets the threshold for synaptic plasticity. Eur J Neurosci 33: 14831492. doi: 10.1111/j.1460-9568.2011.07631.x 
Bradford MM (1976) A rapid and sensitive for the quantitation of microgram quantitites of protein utilizing the principle of protein-dye binding. Anal Biochem 72: 248-254.

Bronowicka-Adamska P, Wróbel M, Zagajewski J (2011) RP-HPLC method for quantitative determination of cystathionine cysteine and glutathione: An application for the study of the metabolism of cysteine in human brain. J Chromatography B 879: 2005-2009. doi: 10.1016/j.jchromb.2011.05.026

Bronowicka-Adamska P, Wróbel M, Zagajewski J (2015) An application of RP-HPLC for determination of the activity of cystathionine beta-synthase and gamma-cystathionase in tissue homogenates. $\mathrm{Ni}$ tric Oxide 46: 186-191. doi: 10.1016/j.niox.2014.09.159

Czubak J, Wróbel M, Jurkowska H (2002) Cystathionine $\gamma$-lyase (EC 4.4.1.1): an enzymatic assay of $\alpha$-ketobutyrate using lactate dehydrogenase. Acta Biol Cracov Ser Zool 44: 113-117.

Deitmer JW (2001) Strategies for metabolic exchange between gila cells and neurons. Respir Physiol 129: 71-81. doi: 10.1016/S00345687(01)00283-3

Dominik PK, Cassidy PB, Roberts JC (2001) A new and versatile method for determination of thiolamines of biological importance. J Chromatogr B 761: 1-12.

Dringen R (2000) Metabolism and functions of glutathione in brain. Prog Neurobiol 62: 649-671.

Dringen R, Gutterer JM, Hirrlinger J (2000) Glutathione metabolism in brain. Metabolic interaction between astrocytes and neurons in the defense against reactive oxygen species. Eur J Biochem 267: 49124916.

Ishigami M, Hiraki K, Umemura K, Ogasawara Y, Ishii K, Kimura H (2009) A source of Hydrogen sulfide and a mechanism of its release in the brain. Antioxid Redox Signal 11: 205-214. doi: 10.1089/ ars.2008.2132

Jurkowska H, Placha W, Nagahara N, Wróbel M (2011) The expression and activity of cystahionine gamma-lyase and 3-mercaptoppyruvate sulfurtransferase in human neoplastic cell lines. Amino Acids 41: 151-158. doi: 10.1007/s00726-010-0606-3

Kartha RV, Zhou J, Hovde LB, Belinda WY, Cheung BWY, Schröder H (2012) Enhanced detection of hydrogen sulfide generated in cell culture using an agar trap method. Anal Biochem 423: 102-108. doi: 10.1016/j.ab.2012.01.001

Kimura H (2013) Physiological role of hydrogen sulfide and polysulfide in the central nervous system. Neurochem Int 63: 492-497. doi: 10.1016/j.neuint.2013.09.003

Kimura Y, Goto Y, Kimura H (2010) Hydrogen sulfide increases glutathione production and suppresses oxidative stress in mitochondria. Antioxid Redox Signal 12: 1-13. doi: 10.1089/ars.2008.2282

Kimura Y, Kimura H (2004) Hydrogen sulfide protects neurons from oxidative stress. FASEB J 18: 1165-1167. doi: 10.1096/fj.04-1815fje

Libiad M, Yadav PK, Vitvitsky V, Martinov M, Banerjee R (2014) Organization of the human mitochondrial Hydrogen sulfide oxidation pathway. J Biol Chem 289: 30901-30910. doi: 10.1074/jbc. M114.602664

Lowry OH, Rosenbrough NJ, Farr AL, Randall RI (1951) Protein measurement with the Folinphenol reagent. J Biol Chem 193: 265-275.
Matsuo Y, Greenberg DM (1958) A crystalline enzyme that cleaves homoserine and cystathionine. J Biol Chem 230: 545-560.

McBean GJ (2012) The transsulfuration pathway: a source of cysteine for glutathione in astrocytes. Amino Acids 42: 190-205. doi: 10.1007/s00726-011-0864-8

Moore PK, Whiteman M (2005) Chemistry Biochemistry and Pharmacology of Hydrogen Sulfide. Springer-Verlag GmbH.

Panthi S, Chung H-J, Jung J, Jeong NY (2016) Physiological importance of hydrogen sulfide: emerging potent neuroprotector and neuromodulator. Oxid Med Cell Longev 2016: 1-11. doi: $10.1155 / 2016 / 9049782$

Paul BD, Snyder SH (2015) Modes of physiologic $\mathrm{H}_{2} \mathrm{~S}$ signaling in the brain and peripheral tissues. Antioxid Redox Sign 22: 411-423. doi: 10.1089 /ars.2014.5917

Perea G, Araque A (2003) New information pathways in the nervous system: communication between astrocytes and neurons. Rev Neurol 36: 137-144.

Predmore BL, Lefer DJ, Gojon G (2012) Hydrogen sulfide in biochemistry and medicine. Antioxid Redox Signal 17: 119-140. doi: 10.1089/ars.2012.4612

Shanker G, Allen JW, Mutkus LA, Aschner M (2001) Methylmercury inhibits the in vitro uptake of the glutathione precursor cystine in astrocytes but not in neurons. Brain Res 894: 131-140. doi: 10.1016/ S0006-8993(01)02342-3

Shanker G, Allen JW, Mutkus LA, Aschner M (2001) The uptake of cysteine in cultured primary astrocytes and neurons. Brain Res 902: $156-163$.

Shibuya N, Koike S, Tanaka M, Ishigami-Yuasa M, Kimura Y, Ogasawara Y, Fukui K, Nagahara N, Kimura H (2013) A novel pathway for the production of hydrogen sulfide from D-cysteine in mammalian cells. Nat Commun 4: 1366-1373. doi: 10.1038/ncomms2371

Shibuva N, Tanaka M, Yoshida M, Ogasawara Y, Togawa T, Ishii K, Kimura H (2009) 3-Mercaptopyruvate sulfurtransferase produces hydrogen sulfide and bound sulfane sulfur in the brain. Antioxid Redox Signal 11: 703-714. doi: 10.1089/ars.2008.2253

Valentine WN, Frankelfeld JK (1974) 3-Mercaptopyuruvate sulfurtransferase (EC 2.8.1.2): A simple assay adapted to human blood cells. Clin Chim Acta 14: 205-210. doi: 10.1016/0009-8981(74)90031-X

Wang R (2012) Physiological implications of hydrogen sulfide: a whiff exploration that blossomed. Pysiol Rev 92: 791-896. doi: 10.1152/ physrev.00017.2011

Wood L (1987) Sulfane sulfur. Methods Ensymol 143: 25-29. doi: 10.1016/0076-6879(87)43009-7

Wróbel M, Jurkowska H, Śliwa L, Srebro Z (2004) Sulfurtransferases and cyanide detoxification in mouse liver kidney and brain. Toxicol Mech Methods 14: 331-337. doi: 10.1080/15376520490434683

Wróbel M, Lewandowska I, Bronowicka-Adamska P, Paszewski A (2009) The level of sulfane sulfur in the fungus Aspergillus nidulans wild type and mutant strains. Amino Acids 37: 565-571. doi: $10.1007 / \mathrm{s} 00726-008-0175-\mathrm{x}$

Zabłocka A, Janusz M (2007) Structure and function of the central nervous system. Postepy Hig Med Dośw 61: 454-460. 